\title{
Niebywała konfabulacja
}

Dorota Zygmuntowicz, Praktyka polityczna. Od Państwa do Praw Platona, Toruń 2011, ss. 643.

\author{
MARIAN WESOEY / POZNAŃ /
}

Oprócz obszernego Wprowadzenia (s. 8-44) i lapidarnego Zakończenia (s. 587-88) książka zawiera dwie nierówne objętościowo części : I. Państwo: mroczna strona „ideału” (s. 45-215); II. Prawa: dionizyjska paideia prawodawcy (s. 218-583), ze znaczącą przewagą dla Praw Platona, co zresztą stanowi główny przedmiot rozważań Autorki. W części I tytuły rozdziału drugiego i trzeciego sugerują swoistą ambiwalentność - (nie)przydatność Kallipolis - (nie)zbędność filozofii - co świadczy o dekonstrukcyjnym zamyśle, ewidentnym także w innych partiach książki. W części II poświeconej w tytule Prawom występuje rozdział trzeci o dynamice ładu społecznego i genezie polis (s. 377-454), w którym zamiast tego dialogu uwzględnione są cztery inne (Państwo, Polityk, Timajos Kritias). Taka oboczność czy niezgodność z nadrzędnym tytułem nie tyle jednak razi, co raczej sama dysproporcja w potraktowaniu poszczególnych ksiąg Nomoi. Zauważmy, że najwięcej wywodów dotyczy księgi I Praw (s. 269-361), niewiele zaś księgi II (s. 361-376), obydwu zresztą z wiodącym wątkiem dionizyjskim, a na resztę dzieła zwrócono nieporównywalnie mniej uwagi. I tak księga III ujęta została jeszcze w oddzielnym rozdziale czwartym (s. 455-512), a najważniejszym w Prawach ośmiu pozostałym księgom (IV-XII) poświęcono na koniec w rozdziale piątym znacznie mniej miejsca (raptem s. 513-583). Nie tyle znów razi tutaj ilościowa dysproporcja i rozległość w podjętej tematyce, czy też preferencja dla dobranych wątków, co właściwie brak merytorycznej i problemowo zasadnej wykładni owych najważniejszych ksiąg Nomoi. W lapidarnym Zakończeniu (s. 587-88), niewspółmiernym z objętością książki, oczekiwalibyśmy podsumowania 
wywodów z poprzednich części i rozdziałów, czego wcześniej w pracy nie poczyniono, a tymczasem znajdujemy tam równie wymyślne i niezrozumiałe dla nas konstatacje.

Już taki ogólny wgląd w zawartość treściową książki, którą trudno nazwać twórczą rozprawą naukową, nie pozostawia wątpliwości, że mimo jej niepomiarkowanej objętości (stron 643), nie może być ona ani przewodnikiem ani komentarzem do lektury platońskich Praw. Autorka nie wnika w problematykę politologiczną Platona, tak jak jest ona stawiana w literaturze przedmiotu, ani nie przedkłada egzegezy wiążących wywodów greckiego filozofa, a tylko doszukuje się wątków, które rozpracowuje niejako w „postmodernistycznej” stylizacji: płynność, otwartość, kruszenie ortodoksji, doprowadzenie na skraj, itp. Już sam niefortunny tytuł Praktyka polityczna, osobliwe wątki tematyczne i sposób ich potraktowania, stanowią jakże naciąganą i niezrozumiałą wykładnię. Stwierdzić to można rzecz porównując z nowszymi opracowaniami, zwłaszcza ze zwięzłą (stron 193) acz niezwykle gruntowną książką André Laksa (A. Laks, Médiation et coercition: pour une lecture des 'Lois' de Platon, Paris 2005; zob. artykuł po polsku: A. Laks, „Prawodawcza utopia Platona", Meander 5 (1999), s. 399-410).

Czytelnik na samym wstępie ma trudność zrozumienia samego tytułu oraz przewodnich tez tego rozwlekłego opracowania. Pomocne może być to, co czytamy dopiero na stronie 41, a także w zakończeniu na stronach 587-588:

„Konsekwencją podejścia znoszącego kategorialną dychotomię pomiędzy tym, jak i o czym dialog jest napisany, i uznającego scenerię za symboliczne tło koherentne z rozwijanymi myślami, musi być powiązanie pytania o niezmienność/dynamikę prawodawstwa z pytaniem o rolę méthe w całym prawodawczym dyskursie Praw. Wykazanie, że związek ten jest w dialogu tworzony za pomocą swoistych dla Praw dramaturgicznych środków, które głęboko angażują rozmówców i wyznaczają im określone funkcje w praktycznych działaniach i doznaniach konstytuujących dynamiczną akcję, dostosowanych do ich mentalnego i kulturowego status quo, oraz wyjaśnienie sensu tego związku i roli, jaka odgrywa on w całym wywodzie Praw - to główny cel proponowanych analiz. Będą one prowadzone według układu 12 ksiąg Praw”.

„W ukierunkowaniu myśli dalej, niż rzeczywiście jesteśmy, w podprowadzeniu na skraj, spełnia się przekaz platońskiej filozofii. [...] W wymiarze praktyki politycznej zdol-

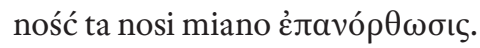

Nie jest to żadna nowa platońska cnota, ale praktyczna, polityczna realizacja sokratejskiego bycia jako ciągłej refleksji i sprawdzania siebie. [...]

Enanórthosis nie jest pojęciem, lecz dynamicznym i konkretnym zdarzeniem w dyskursie, jakim są Prawa. Jako coś realnego objawia się tylko w jego wnętrzu, gdyż zaangażowanie i ciągłe weryfikowanie emocjonalno-intelektualnej wiarygodności stanowi jej istotę. [...] Nie do niej należy dążyć, gdyż to ona właśnie wyraża dążenie, krusząc wszelkie skostniałości, które je hamują lub odwodzą od właściwego kierunku. Nie ona jest celem, lecz środkiem, tak jak filozofia w Państwie jest środkiem do obnażenia pozornej wartości politycznych konstruktów. Jako taka może być tylko ukierunkowaniem, mentalnym i emocjonalnym kompasem wskazującym prosty kierunek (orthós) ku cnocie”. 
Trudno zaiste ze zrozumieniem uchwycić i myślowo ogarnąć owe rozwlekle i nie rzadko luźne wywody, trudno też streścić je w perspektywie znajomości dialogów Platona, jako że Autorka na swój wartościujący i na poły literacki sposób rozpisuje się nadmiernie, nie starając się spójnie syntetyzować. Tym samym okazuje więcej wylewności słownej, nawet w szczegółach, a mniej wnikliwości (akrybii) i samokrytycyzmu w swych pomysłach, które wymagałyby wpierw przedyskutowania ze specjalistami. Zdaje się wprawdzie orientować w głównej literaturze przedmiotu, ale własne stawiane tezy trzeba uznać za niesamowita konfabulację. Wątpliwości, propozycje merytorycznych korekt i nieodzownych dla spójności skrótów, można by przedłożyć prawie na każdej stronie recenzowanej książki. Tutaj jednak ograniczymy się do uzasadnienia kilku zarzutów pod adresem głównych jej tez.

\section{„Praktyka polityczna” - mentalna interakcja między rozmówcami?}

Przede wszystkim sam nośny tematycznie tytuł „Praktyka polityczna...” jest bezzasadny i dla niezorientowanego czytelnika może być mylący, zarówno w jego brzmieniu potocznym, jak i w tym osobliwym sugerowanym w książce. Przecież u Platona w Politei (II, 369 a; IX, 592 a-b), jak i w Prawach (III, 702 e) stwierdza się wprost, że owa wzorcowa polis zakładana jest w logosie czy $w$ logosach (tj. w rozmowie, nie w samej myśli) bez odniesienia do aktualnej rzeczywistości, stąd też w wypadku Nomoi trafne jest określenie „prawodawczej utopii” (zob. wspomniany powyżej artykuł A. Laksa, „Prawodawcza utopia Platona”). Pojęcie „praktyki politycznej” bliższe byłoby Arystotelesowej „filozofii praktycznej”, której Platon w ten sposób nie pojmował, jako że techne politike stanowiła dlań umiejętność poznawczą (zob. E. Berti, Filosofia pratica, Napoli 2004). Tytuł rozprawy jest wiec całkiem nieadekwatny do owej politologicznej i legislacyjnej wizji Platona, dyskusyjnej utopii oderwanej od realiów i praktyki ówczesnej polityki, co odnotował już Arystoteles (Pol. II, 1266 a 31n.) i stanowi communis opinio wybitnych badaczy.

„Platon nie ma do zaoferowania wiedzy realnej i obiektywnej, ani politycznej ani filozoficznej. Lecz utrzymuje, iż może powiedzieć z pewnością, że życie człowieka jest dobre lub złe na bazie pewnego modelu wiedzy, która może być jedynie ogólnie i idealnie określona" (F. Trabattoni, Platone, Roma 1998, s. 327 - tłum. M.W.).

„Nie należy jednak popełniać błędu sądząc, że polis w Prawach przedstawiać miała schemat realizacji „praktycznej” utopii kallipolis wzmiankowanej w Politei. Chodziło oczywiście wciąż o model utopijny, czy to drugiego rzędu, czego praktykowalność wymagałaby ze swej strony dostosowania do okoliczności historyczno-politycznych. Jednakże ten model uwzględniał dane antropologiczne uznane przynajmniej 'na razie' (V, 740 a) za niezmienne, zwłaszcza co do tej przemożnej więzi „przyjemności” (V, 733 a), związanej z wyzbywaniem się afektywnym i patrymonialnym, jaki ukazał się teraz — jak to byłoby dla Arystotelesa - konstytutywnym dla ludzkiej natury" (M. Vegetti Quindici lezioni su Platone, Torino 2003). 
Odniesienie „praktyki politycznej” do czysto dyskusyjnej wizji Platona stanowi oksymoron (contradictio in adiecto) - pojęcie praktyki i dyskusji wzajemnie się wyklucza - chyba że dopuszczamy jakąś stylizację metaforyczną. Jeśli rozmyślanie jest pewną aktywnością, to można je metaforycznie nazwać „praktyką”, jak np. w medytacji wschodniej utwierdza się umysł w czystej duchowości. Jednakże Autorka, nie eksplikując tego dokładniej, ma na myśli jeszcze inne osobliwe pojęcie ‘praktyki mentalnej', o czym poniżej.

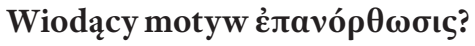

Na podstawie częstotliwości w Prawach Platona słów z rdzeniem orthos Autorka pochopnie i opacznie przypisała temu wymyślny sens dramaturgiczny praktyki rozgrywającej się między sędziwymi interlokutorami, Gościem z Aten, Kleiniasem i Megillosem.

„Pytanie zatem, jakie stawiamy, brzmi: jakie znaczenie nadaje Platon słowu

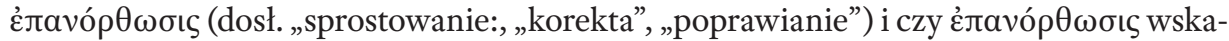
zuje na nową cnotę polityczną Platona, do której zdobycia uzdalnia właśnie praktyka, jakiej poddani są sędziwi rozmówcy dialogu? [...] Wzajemna i ciągłą interakcja miedzy rozmówcami, nowa mentalna rzeczywistość, jaką wspólnie tworzą, najczęściej nieprzewidywanie dla nich samych - oto przekaz Platona" (s. 42-43).

Niestety, wbrew temu, co czytamy w recenzowanej książce, u Platona w ogóle brak słowa ع̇javó $\theta \omega \sigma ı \varsigma$ w formie rzeczownika - pojęcia, czego Autorka zdaje się mieć świadomość, a mimo to myląco się nim posługuje. Np. na stronie 260: „Ze względu na fakt częstego występowania w Prawach słowa غ̇лavó $\rho \omega \sigma ı$, zawierającego w swym znaczeniu ambiwalencję tradycji i repetycji oraz odnawiającej zmiany w imię osiągania pewnego prawidłowego stanu (orthótes), można nazwać tę przemianę epanorthozą” (sic?).

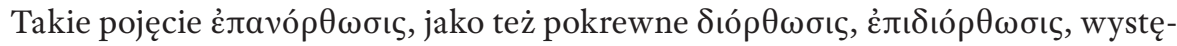
puje natomiast u Arystotelesa oznaczając skorygowanie w sensie moralnym i prawnym.

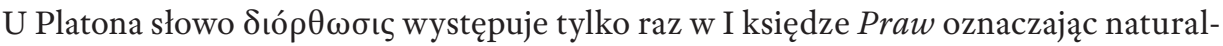
ne „poprawianie” (doskonalenie) w sensie wychowawczym, które wymaga prawidłowej muzyki i całokształtu pa idei (poniżej przekłady własne - M.W.):

$\checkmark$ „Takie zaś podług natury poprawienie nie byłoby możliwe bez prawidłowej muzyki jasno i wystarczająco do ujęcia w wywodach, muzyka zaś bez wszelkiej paidei nie byłby znów możliwa; te kwestie wymagają wielorakich wywodów" (I, 642 a 3). - Nieco zniekształcony przekład tego miejsca z odniesieniem do $\mu \varepsilon ́ \theta \eta$ (picia wina) czytamy na stronie 242.

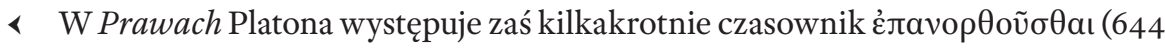
b 3; 653 d 4; 769 c 4; 772 b 3; 772 c 3; 809 b 5) tak samo dla określenia zwykłego 'poprawiania', 'ulepszania' czy ‘doglądania' stanowionych praw. W księdze VI jest zalecenie następujące:

〈 „Wpierw spisać prawa na sposób ścisły podług możności wystarczająco, następnie z upływem czasu te poglądy w czynie wyprobowując, czy sądzisz, że jakiś 
prawodawca jest na tyle bezmyślny, iż nie wie, że wiele z nich trzeba pozostawić

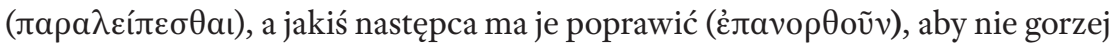
tylko lepiej ustrój polityczny i ład wciąż się stawał w zakresie polis przezeń zakładanej? [...]

《 Gdyby ktoś miał jakąś moc względem tego, czynem i słowem w pewien sposób nauczać, czy to większe czy mniejsze mając o tym pojęcie, jak trzeba pilnować

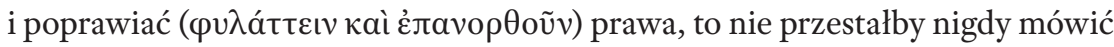
o tym, zanim nie dotarłby do końca - celu" (VI, 769 d-e).

Nieco inny przekład tego tekstu o innej wymowie podaje Autorka na stronie 570. Chodzi tu wszak o stopniowe doglądanie i poprawianie stanowionych praw, aż wreszcie osiągnie się ich cel (ukończenie), nie zaś o ciągłą ludzką niedoskonałość i zmienność w tym zakresie. Ten sam sens w tej samej księdze:

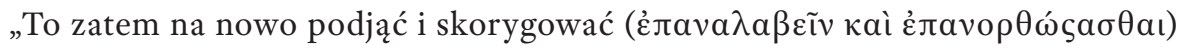
i wszystkie zwyczaje uregulować wspólnie dla kobiet i mężczyzn, to jest lepsze dla dobrostanu polis" (VI, 781 b 4).

I jeszcze dwa miejsca w księdze XII, gdzie chodzi takoż o utwierdzanie, korygowanie, czyli o doglądanie stanowionych praw, nie zaś o „potencjał niedoskonałości”.

„Są bowiem pośród wielu zawsze jacyś ludzie boscy - choć nieliczni - całkiem godni rozpoznania, zrodzeni raczej w miastach dobrze rządzonych prawami, a nie w tych co źle, w ślad których wciąż trzeba, by ten kto zamieszkuje w tych miastach dobrze rządzonych, wyruszył na morze i ziemie, dociekać, jakby był niewzruszony, jedne z rzeczy prawych

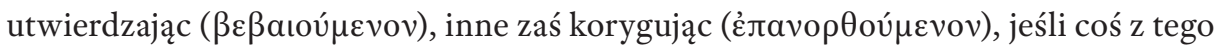
pozostaje. Albowiem bez takiego doglądu ( $\theta \varepsilon \omega \rho i ́ a)$ i dociekania nigdy doskonale nie ostaje polis, ani gdy źle się jej dogląda" (Prawa XII, 951 d-c).

„Stąd trzeba, aby strażnicy prawa przygotowali to co nieodzowne dla powsta-

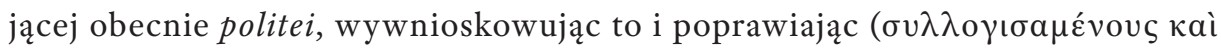

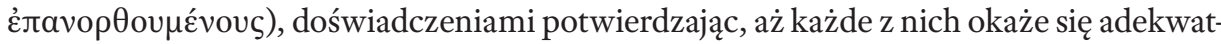
nie przyjęte, a wtedy dochodząc do końca, jako niewzruszone w ten sposób pieczętując, posługiwać się nimi przez całe życie"(XII, $957 \mathrm{a}-\mathrm{b}$ ).

Zauważmy, że podane powyżej cytaty to wyłączne wypowiedzi samego Gościa z Aten, z którym oczywiście zgadzają się obydwaj rozmówcy, bez jakiegoś cienia ich wzajemnej udramatyzowanej 'praktyki mentalnej'. Gdzież tu doszukiwać się dramaturgii?! Chodzi po prostu o wymóg poprawiana, ulepszania i ostatecznie utwierdzenia (opieczętowania) niewzruszonych praw.

U Arystotelesa analogiczny wymóg występuje zarówno w formie rzeczownikowej

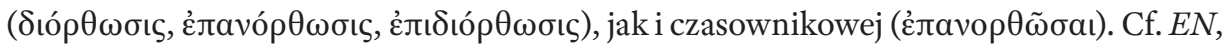
1165 b 18; oznaczając głownie poprawianie norm moralnych i praw. Cf. fr. 611.77 Rose; SE 176 b 35, Pol. 1275 a 20; 1321 b 21; 1317 a 35. Polityk (mąż stanu) ma właśnie za zadanie naprawianie istniejących ustrojów: „Toteż nie mniejszym dziełem jest poprawia-

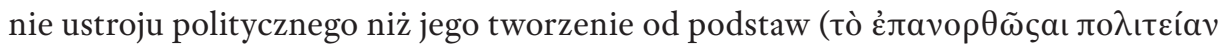

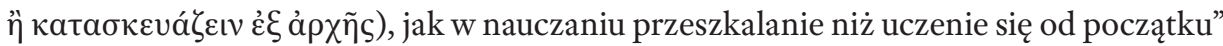
(Pol. IV, 1289 a 8$)$. 
Na marginesie dodajmy, że wymóg poprawiania i ulepszania był typowy także dla perypatetyków; wykłady Teofrasta miały sprawiać „moralne ulepszenia”

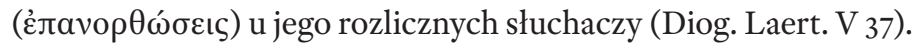

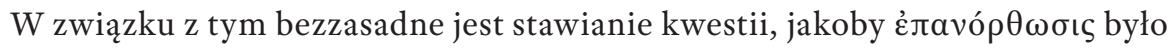
cnotą polityczną u Platona (czy nawet u Arystotelesa), jako że samo „poprawianie” w ogóle nie podpada pod sokratejską charakterystykę owych cnót - wad. Całkiem więc chybione jest przypisanie w Prawach Platona owej દ̇ं $\alpha$ vó $\rho \theta \omega \sigma \iota \varsigma$ takich znamion hermeneutycznych, jakby odgrywała ona istotna rolę w dramaturgii dialogu. W tym kontekście to po prostu idée fixe!

\section{Politeia - mimesis dramatyczna najlepszego życia}

Tutaj znów musimy zacytować w naszym dosłownym przekładzie partię tekstu Praw, aby stwierdzić, że przyjęta przez Autorkę interpretacja jest wyrwana z kontekstu i całkiem opatrzna. Otóż w VII księdze znajdujemy wyborne skojarzenie w stylizacji dramaturgicz-

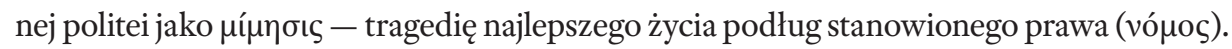

„Najczcigodniejsi goście, my sami jesteśmy poetami tragedii według możności najpiękniejszej i najlepszej. Cały nasz bowiem ustrój polityczny (ло入ıєєía) ustanowiony

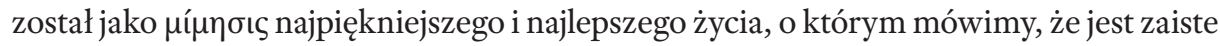
najpiękniejszą tragedią. Poetami jesteście wy, poetami jesteśmy i my w tej samej dziedzinie; jesteśmy wobec was rywalami i antagonistami w zakresie najpiękniejszego dramatu, którego tylko prawdziwe prawo zdoła z natury dopełnić, bo taka jest nasza nadzieja.

Nie myślcie, że pozwolimy wam łatwo przybyć do nas i zaszczepić wasze sceny na naszej agorze, i wprowadzić aktorów o pięknym głosie, bardziej brzmiących od nas, że pozwolimy wam demagogicznie działać na dzieci i kobiety i cały tłum, mówiącym o tych samych zwyczajach rzeczy różne od naszych, a nawet w większości wypadków prze-

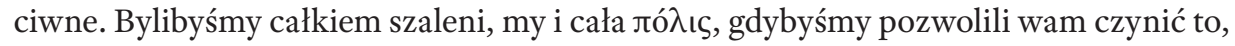
o czym teraz mowa, zanim zarządcy ocenią, czy wasze słowa i zwyczaje utworzyliście odpowiednimi dla publicznego przedstawienia czy też nie" (VII, 817 b).

Mamy tu ironiczną scenę uprzejmego powitania i wyproszenia zarazem przybyłych poetów, co stanowi nawiązanie do mimetyki dramatycznej znanej już z Politei Platona. Mamy tu również motyw 'najlepszego życia', co - moim zdaniem - stanowi nawiązanie

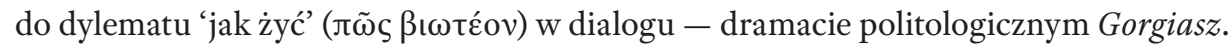

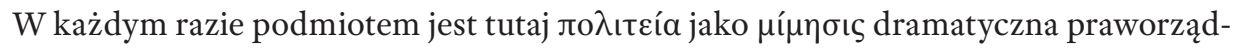
nego życia. Wszelako wbrew wszelkim interpretacjom tego zdumiewającego passusu Autorka stwierdza, że nie chodzi tu o zarys politei, lecz o „żywą relację z procesu nabywania przez rozmówców prawodawczych predyspozycji — innymi słowy, gdy bohaterem owej tragedii uczynimy nie Magnezję, lecz trzech starców. Ich rozmowa usytuowana w dionizyjskiej scenerii, nie służy jedynie zarysowaniu ustroju Magnezji” (s. 575).

To już coś więcej niż nadinterpretacja! Jak można tak przeinaczyć tekst, w którym w ogóle brak osi dramatycznej typowej dla innych dialogów Platona. Gdyby faktycz- 
nie Prawa nosiły takie znamiona, to Arystoteles - wielki ówczesny teoretyk dramatu i uczeń Platona - nie omieszkałby tego stwierdzić. Tymczasem znał on i oceniał ten dialog w wymiarze argumentacyjnym i merytorycznym. Rozmówcy w Prawach - to już nie skonfliktowani i nieustępliwi adwersarze, jak w Gorgiaszu czy Protagorasie, lecz leciwi, prawomyślni i zdominowani przez przydługie monologi Gościa z Aten w zupełnie innej scenerii od agonu (rozgrywki i napięć) dialogów sokratejskich. Nawet w Gorgiaszu, najbardziej udramatyzowanym dialogu politologicznym, akcja rozgrywa się przecież nie w mentalności rozmówców ('praktyka polityczna'?), a tylko w napięciu dyskusyjnym i problemowym.

Jak trafnie stwierdziła Maria Maykowska: „współudział w rozmowie Kleiniasa i Megillosa, nieco żywszy 'w prologu', słabnie i w dalszym ciągu dzieła. Z rozmówców stają się słuchaczami. Zadają czasem pytania, proszą o wyjaśnienie, wyrażają wątpliwości, dziwią się słowom Ateńczyka lub im przytakują. Cały trud wywodów bierze Ateńczyk na siebie. [...] W Prawach nie ma zmagania się z problemami, wytężonego wysiłku znalezienia ich rozwiązania, nie ma dramatycznego napięcia” (Platon, Prawa, tłum. M. Maykowska, Warszawa 1960, s. XXVIII).

Dodajmy jeszcze, że według A. Laksa owa tragiczność politei Magnezji wyraża się w nierozwiązywalnym konflikcie między ustawodawczym ideałem racjonalnej perswazji i koniecznością wymierzania kary dla wymuszenia posłuszeństwa (A. Laks "Plato's 'truest tragedy' (Laws, 817 a-b)”, w: C. Bobonich (ed.), A Critical Guide to Plato's Laws, Cambridge 2010, s. 217-231).

\section{Dygresja parenetyczna}

Tyleż ważny co trudny problem to rozpoznanie zarówno kompozycji globalnej, jak i poszczególnych ksiąg Praw. Autorka jednak nie starała się pójść tym tropem, aby wyrobić sobie klucz (czy klucze) do lektury i egzegezy tego monumentalnego dzieła. Pochopnie bowiem zawierzyła swej własnej, a nie przedyskutowanej w środowisku znawców, interpretacji. Wgląd w całość na podstawie nowszych opracowań daje nam inne rozpoznanie dwunastu ksiąg Praw: pierwsze trzy stanowią prolegomena, kolejnych pięć (IV-VIII) wizję organizacji materialnej, politycznej, społecznej, prawnej i gospodarczej polis, a cztery ostatnie (IX-XII) to dopiero właściwy kodeks legislacyjny. W swej pracy Autorka ograniczyła się głównie do pewnych wątków trzech pierwszych ksiąg, podczas gdy problematyka pozostałych - zaiste najważniejszych ksiąg Nomoi - nie tylko, że nie została podjęta adekwatnie do ich zawartości treściowej, ale i mylnie zinterpretowana w dość osobliwym naginaniu i wartościowaniu.

Musimy tu poczynić pewne uwagi, aby zaznaczyć nasz odmienny pogląd od tego w recenzowanej rozprawie. Rozległy projekt politologiczny Platona należałoby uchwycić w całościującej perspektywie, uwzględniając piętno polityki w jego żywocie i twórczości ( pro vita sua - List VII), której wykładnia wyrażała się w takiej oto kolejności: Apologia Sokratesa - Kriton - Gorgiasz - Politeia - Polityk - Prawa. Krótko mówiąc, od 
nieprawego uśmiercenia Sokratesa wraz z jego przesłaniem, że 'nikt godziwy w polityce się nie ostaje', a mimo to należy przestrzegać ojczystych praw, poprzez ową „drugą apologię” Sokratesa (Gorgiasz) jako anatomię nieprawości, czyli rozprawienie się z demagogią

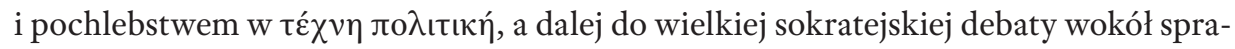
wiedliwości i paidei w projekcie wzorcowego ustroju politycznego (Politeia), po czym następuje swoisty przełom ( $\delta \varepsilon u ́ \tau \varepsilon \rho o \varsigma ~ \pi \lambda$ oũ $)$ zapodany przez Gościa z Elei, aby usankcjonować stanowione normy prawne (Polityk, 300 c). Podjęte to zostało zamaszyście przez późnego Platona, lecz ogłoszone w dwunastu księgach dopiero po jego śmierci zapewne za sprawą Filipa z Opuntu (Diog. Laert. III 37).

Arystoteles znał jeszcze taką wersję Praw Platona, gdzie protagonistą był Sokrates. „Wszystkie wywody Sokratesa - jak pisał - wykazują wyszukaność i kunszt, nowatorstwo i dociekliwość, ale czy trafne to wszystko, trudno uznać” (Pol. II 6, 1265 a 10). Natomiast w przeredagowanej wersji, do której Filip z Opuntu dopisał trzynastą księgę Epinomis, zamiast Sokratesa występuje Ateński Gość, co - moim zdaniem - wiązało się z wymownym zastąpieniem sokratejskiej 'filozofii’ pitagoryzującą 'mądrością' matematyczną. Bliżej o intencjach Filipa z Opuntu w perspektywie 'przeredagowania’ platońskich Nomoi traktujemy we wstępie do polskiego przekładu Epinomis, przy współautorstwie Jerzego Pawliszcze (w przygotowaniu).

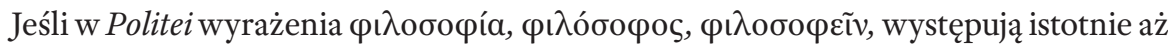
109 razy, to w Prawach jedynie w formie czasownikowej tylko 2 razy pojawia się to słowo i w kontekście raczej drugorzędnym. Z kolei w Epinomis zupełnie brak wzmianki o filozofii czy filozofowaniu. O wyeliminowaniu filozofii z myśli późnego Platona nie może być mowy (planował on bowiem istotny dialog o tym tytule Filozof), a tylko z tekstu przeredagowanych pośmiertnie Nomoi, gdzie miejsce wieńczącej dialektyki - filozofii przejmuje pitagoryzująca paideia muzyczna i matematyczna.

W związku z tym należy zachować ostrożność w przypisywaniu Platonowi in extenso autorstwa Praw, której znana nam wersja nosi wyraźne znamiona przeróbki. Zapewne Platon w tej postaci nie ogłosiłby swego dzieła. Wiemy ze źródeł antycznych, że do końca życia ciągle poprawiał swe dialogi, zwłaszcza Politeię. Dlatego postulowany w recenzowanej książce „cudowny chaos” - to coś zupełnie nie w jego stylu. Po śmierci Platona nawet bezpośredni jego uczniowie (Speuzyp, Ksenokrates, Arystoteles) nie tylko, że nie podzielali jego poglądów, ale i konkurowali z sobą wzajemnie. Podobnie Filip z Opuntu miał powody, aby na swój pitagoryzujący sposób zaadaptować Platona. Przepisując jego niedokończone Nomoi i nadając im księgi mógł odpowiednio materiał przeformułować czy nawet przeinaczyć dla swej własnej — już nie sokratejskiej - wizji politologicznej. Jest to zrozumiałe, zresztą Autorka też na swój sposób intencjonalnie, wybiórczo i wymyślnie ujmuje Platona z przesadnym nastawieniem na dionizyjską paideię, $\mu \varepsilon ́ \theta \eta$, biesiadny chaos, kruszenie ortodoksji, દ̇javó $\theta \omega \sigma ı \varsigma$ itp.

Tak czy inaczej w rozległym tekście Praw da się zauważyć pewne napięcie między platońską pozostałością sokratyzmu i pitagoryzującym nastawieniem ich wydawcy. Nie miejsce tu o tym traktować ani też podnosić owej żywo dyskutowanej dziś problematyki stosunku Praw do Politei Platona. Inaczej niż w recenzowanej książce zależność tą nale- 
żałoby ujmować raczej jako swoiste uzupełnienie aniżeli kontynuację czy przezwyciężenie projektu politologicznego twórcy Akademii (zob. A. Laks, Médiation et coercition: pour une lecture des 'Lois' de Platon, Paris 2005).

\section{Uwagi terminologiczne}

Tak samo postawić można szereg zarzutów co do treści i charakteru wywodów poczynionych w trzech rozdziałach części I rozprawy. Zajęłoby to jednak zbyt wiele miejsca. Ograniczymy się do kilku uwag terminologicznych. W zamieszczonym na końcu Indeksie pojęć (s. 618-628) podane są ważniejsze wyrażenia greckie wraz z ich odniesieniem do stron książki. W większości ich polskie odpowiedniki są trafne dobrane. W takim indeksie pojęć należałoby jednak nie tylko podać strony w tekście książki, ale i konkretne miejsca w dialogach Platona, jako że niektóre wyrażenia występują tylko w Politei, ale

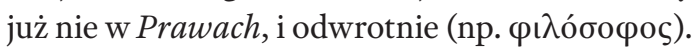

Zabrakło jednak wyszczególnienia jednej z czterech kardynalnych cnót prawodawcy

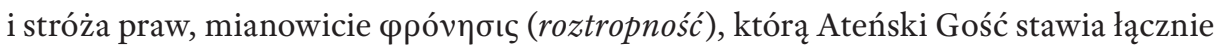

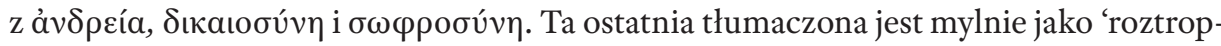

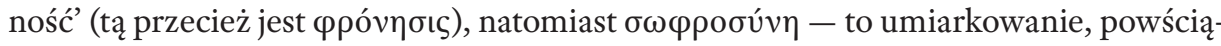

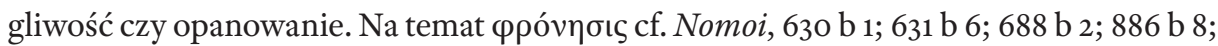
964 b 6. Sposób pojmowania tych czterech cnót można przyjąć za Cyceronem: prudentia, iustitia, fortitudo, temperantia.

Dodany, że tłumaczenie wyrażenia $\delta \varepsilon v ́ \tau \varepsilon \rho o \varsigma ~ \pi \lambda$ oũ j jako 'druga żegluga' stanowi lapsus, gdyż w metaforze Platona chodzi dosłownie o ‘drugie płynięcie’, gdy nie wieją wiatry, a zatem o ‘wiosłowanie', które przecież nie jest ‘żeglowaniem’ - płynięciem o żaglach.

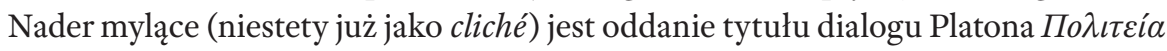
i Cycerona De republica jako Państwo. W grece i łacinie takie wyrażenia, jak politeia, res publica, civitas, regnum itp., nie oznaczały naszego pojęcia „państwa”. Machiavelli miał pierwszy użyć terminu „Stato” dla określenia tego, co w nowożytności nazywa się „Państwem” (État, Estado, Staat, State, itp.). Tytuł owego dialogu należy po prostu podawać jako Politeia, jak trafnie to czynią niektórzy, m.in. J. Wikarjak, E. Wolicka, a piszący te słowa niejednokrotnie wskazywał na taką zasadność.

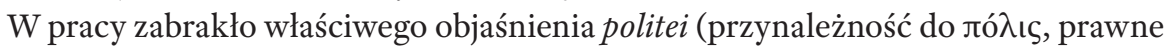
obywatelstwo, życie obywatelskie, ustrój polityczny, konstytucja, forma rządu, sprawowanie władzy) z odniesieniem również do Polityki Arystotelesa w wielu przecież pokrewnych i żywo dyskutowanych podówczas kwestiach.

Ponadto niektóre z używanych wyrażeń, jak np. „dramaturgiczna narracja”, „sokratejski dyskurs”, w odniesieniu do Platona są nieścisłe i mylące. Wyznacznikiem dramatur-

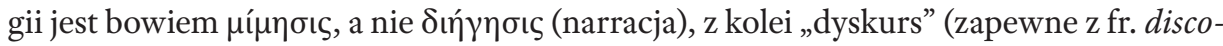
urs) jest raczej mową, monologiem, a nie dialogiem (sokratejskim). 


\section{Uwagi co do anonsu}

Na tylnej okładce książki widnieje anons o takim początku: „Platon — filozof polityki, to przeciwnik demokracji, orędownik państwa totalitarnego, twórca nierealnej wizji społeczeństwa doskonałego. Czyżby?”

Jednakże w książce trudno znaleźć obronę Platona jako przeciwnika demokracji (ateńskiej). Zresztą lektura jego dialogów politologicznych nie pozostawia co do tego wątpliwości. Co zaś tyczy się zarzutu totalitaryzmu i nierealnej wizji ustroju politycznego Autorka podejmuje zamaszystą próbę swoistego 'wybielenia' Platona pod tym względem. Kwestionuje więc „pogląd, iż Państwo jest szczytem politycznych wizji Platona; osłabia przekonanie, że stałość i niezmienność norm cechują dobry ustrój”. Tym samym upatruje w Prawach taki „szczyt” wraz z ich duchowym dynamizmem i gotowością „do kruszenia wszelkiej ortodoksji usypiającej myśl”. Tutaj nasuwają się przynajmniej dwie kwestie sporne.

Po pierwsze, czy faktycznie Prawa są rewizją, złagodzeniem bądź nawet przezwyciężeniem ‘totalitaryzmu' Politei? — Osobiście uważam, że stanowią one jej uzupełnienie w wymiarze raczej pitagorejskim niż platońskim (zob. powyżej). W żaden zaś sposób nie czynią tej utopii politologicznej bardziej realistyczną i oświeconą, przynajmniej w naszej humanistycznej perspektywie. Podzielam w tym względzie także argumenty Arystotelesa (Pol. II 1-2).

W związku z tym - po drugie, trudno przyjąć argumentację, jakoby przesłaniem Platona było jedynie obnażanie ograniczeń i niebezpieczeństw „wszelkich politycznych ideałów i konstrukcji dążących do doskonałości”. Wprawdzie w sposób ortodoksyjny (dogmatyczny) Sokrates i Gość z Aten nie stawiali nigdy kwestii, lecz w wymiarze dyskusyjnym i perswazyjnym (jak owe wstępy do praw), to jednak nie można przypisać im jedynie „kruszenia wszelkiej ortodoksji” bez postulowania radykalnych przecież rozstrzygnięć prawodawczych.

Niezrozumiałe jest dla nas również stwierdzenie: „Ocena słuszności jego prawodawczej propozycji, jak i kontynuacja metody krytycznego myślenia, od pokoleń wpisują się w tradycję każdej autentycznej sztuki politycznej”. Któż tak słusznie oceniać miał utopię Platona, aby wykorzystać ją w teorii i praktyce polityki? Czy można ją w ogóle uznać za racjonalną i oświeconą?

\section{Wnioski}

Imponujące wydaje się obszerne wykorzystanie literatury przedmiotu (pewne pozycje szczególnie upodobane). Odnieść można przy tym wrażenie, że na pierwszym planie, oprócz swych naciąganych pomysłów, Autorka liczyła się bardziej z literaturą przedmiotu niż z samymi tekstami Platona. Jednakże przekłady z greki podane zostały w odautorskim tłumaczeniu, jak mogłem się zorientować, są one nie zawsze poprawne merytorycznie. Wszak to trudne i tutaj nie stawiałbym zarzutów, choć rzecz wymaga- 
łaby wcześniejszego przejrzenia przez hellenistę i znawcę Platona. Z drugiej zaś strony, jak wyjaśnić i ocenić ewidentne przeinaczenia i mylną egzegezę. Być może to wynik młodzieńczej beztroski i wpływ postmodernistycznej stylizacji, a także brak profesjonalnej dyskusji z zagranicznymi znawcami przedmiotu.

Teksty pisane przez Autorkę zdają się nie mieć wyraźnie i ściśle nakreślonego zadania, pozostawiając niekiedy w zawieszeniu rozważaną tematykę i bez oczekiwanej konkluzji. Osobliwy dobór tematyki daje posmak raczej literacki aniżeli prozy naukowej. Daje się przy tym zauważyć pewną wybiórczość i wartościowanie w podjętych wątkach. Szkoda tylko, że w przedmiocie rozprawy nie rozpoznała wnikliwości i rangi filozofii politycznej Arystotelesa. Albowiem polemiczne wywody Stagiryty wobec sokratejskiej politei i praw są dla nas najbliższym świadectwem w tym zakresie i pewną propozycją rozstrzygnięć na sposób wyważony i filozoficznie nam bliższy.

Przykro stwierdzić, ale książka ta jest wielkim, ale chybionym opracowaniem podjętej problematyki. W dzisiejszej 'postmodernistycznym świecie' można czytać Platona, „jak się żywnie komuś podoba” (anything goes), wszelako powinnością naszej pracy naukowej jest wskazać na pomyłki, przeinaczenia i wątpliwości. Wskazaliśmy na to jedynie w minimalnym stopniu, niestety za późno dla dobra sprawy. Opublikowanie tak obszernej książki w tej bezkrytycznej i nieprzedyskutowanej profesjonalnie postaci nie powinno mieć miejsca. 
